\title{
Glycogen Metabolism of Human Diploid Fibroblast Cells in Culture. II. Factors Influencing Glycogen Concentration
}

\author{
Salvatore DiMauro ${ }^{[27]}$ and William J. Mellman \\ Departments of Neurology, Pediatrics, and Human Genetics, University of Pcnnsylvania, Philadelphia, Pennsylvania, USA
}

\begin{abstract}
Extract
Glycogen is stored by human diploid fibroblast cells in culture when sufficient glucose is available in the medium, and is utilized when glucose is removed or exhausted. Restoration of glucose to the medium causes a prompt increase of glycogen; the effects of serum, insulin, and cytochalasin B on this glycogen reaccumulation in glucosestarved cells were investigated. Serum was required for maximal resynthesis of the polysaccharide. Insulin initially appeared to be the needed serum factor; addition of the hormone $(4 \mathrm{mg} / 100 \mathrm{ml})$ and glucose to the medium restored cell glycogen to maximal levels (i.e., levels comparable with those obtained by addition of fresh serum and glucose). For replenishment of glycogen, insulin could substitute completely for serum after cells had been depleted of glycogen in the presence of serum. If cells were depleted of glycogen in the absence of serum, insulin and glucose did not restore glycogen to the same concentration as fresh serum and glucose, which indicates that cells may require other serum factors in addition to insulin for maximal resynthesis of glycogen.

Cytochalasin B added to the medium ( $1 \mu \mathrm{g} / \mathrm{ml}$ ), in the presence or absence of serum and insulin, caused about $80 \%$ inhibition of glycogen resynthesis.
\end{abstract}

\section{Speculation}

These studies demonstrate that human fibroblast cells store and utilize glycogen in a reproducible way. Such a system will be advantageous in the study of glycogen control mechanisms, and hence in the identification of cells where the control of glycogen metabolism is genetically altered.

The observation of an insulin effect on glycogen reaccumulation suggests that this approach might be profitable in the study of diabetes in vitro.

\section{Introduction}

Human fibroblast cells in culture accumulate glycogen when glucose is available in the medium $[1,5,17]$. In the preceding paper [7] we reported that glycogen disappears in a predictable way after glucose starvation of normal cells or cells from patients with some glycogen storage diseases. The present studies are concerned primarily with glycogen reaccumulation in glycogen-depleted cells. We examined the effect of serum, insulin, and cytochalasin B on glycogen resynthesis. 


\section{Materials and Methods}

\section{Preparation of Glycogen-depleted Cell Cullures}

Cells from a variety of human fibroblast cell lines in the period of regular cell multiplication were passaged at weekly intervals [12] in glass milk dilution bottles with medium containing Eagle's minimal essential components plus $10 \%$ fetal calf serum $(\mathrm{v} / \mathrm{v})$ until the time of the experiment. None of these cells were derived from patients with glycogenoses. For the experiments described in Figures 2-6, the cells were maintained on glucose-containing medium until day 10 of the subculture, and then incubated until day 13 on medium without glucose. Glucose starvation was done in the presence of serum (Figs. 2, 3, 5, 6) and in both presence and absence of serum (Fig. 4). The glycogen
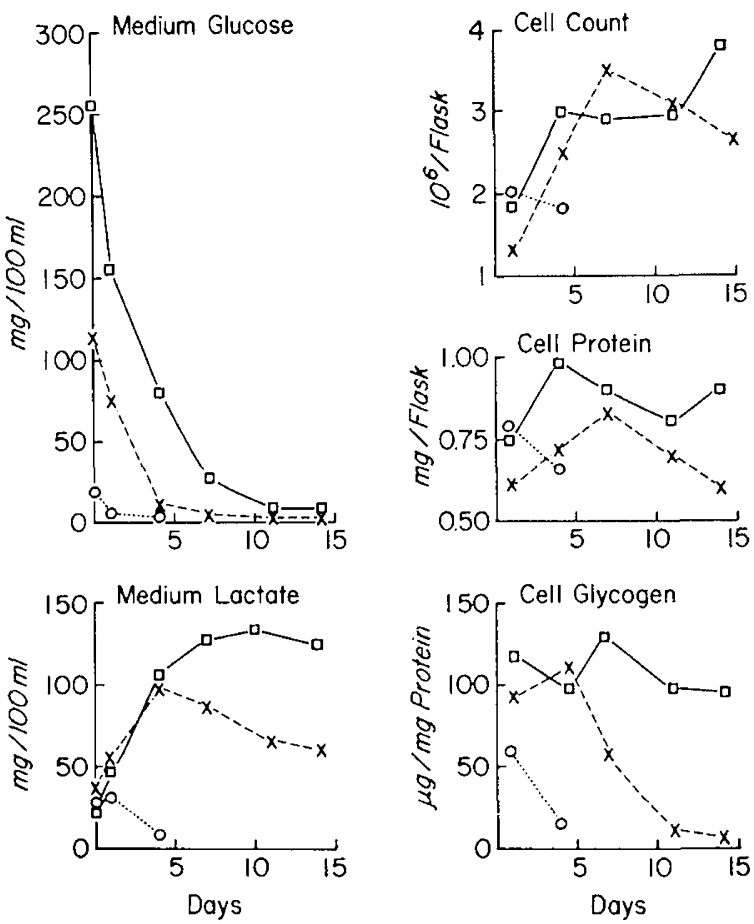

Fig. 1. Influence of glucose concentration in the medium on the metabolism of glycogen. Replicate cultures (grown in milk dilution bottles) of a control cell line were incubated for I week in standard medium conditions and then divided into three groups. Each group of cultures was placed in a medium with one of three different glucose concentrations: $19 \mathrm{mg} / 100 \mathrm{ml}$ (glucose

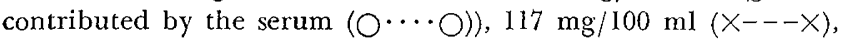
and $254 \mathrm{mg} / 100 \mathrm{ml}(\square-\square)$. Initial lactate concentrations (2l-25 mg/100 ml), similar in the three groups, reflected lactate present in the serum. Cells were harvested from each group 1, 4, 7,11 , and 14 days later and the following measurements were obtained: medium glucose, medium lactate, cell count, total cell protein, cell glycogen. The cells on low glucose did not survive until the 7 th day, so data were only available for days 1 and 4 .

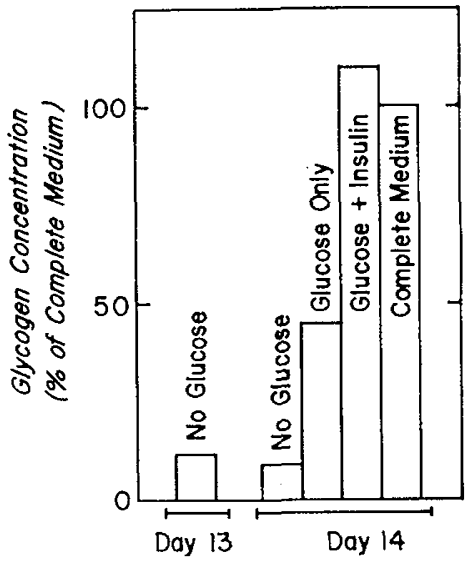

Fig. 2. Effect of medium components and insulin on glycogen reaccumulation after depletion by glucose starvation. Cells from eight different cell lines were glucose-fed until day 10 , then glucose-starved until day 13 (see Materials and Methods). The cultures were divided into four groups treated as follows: $(I)$ no glucose (day 14): cultures were continued on the same glucosefree medium added on day 10; (2) glucose only: medium was not replaced but concentrated glucose was added to final medium glucose concentration of $100 \mathrm{mg} / 100 \mathrm{ml}(\mathrm{w} / \mathrm{v})$ without significant change in volume; (3) glucose + insulin: scrum-free medium containing glucose, $100 \mathrm{mg} / 100 \mathrm{ml}$, and insulin, $4 \mathrm{mg} / 100 \mathrm{ml} ;(4)$ complete medium: medium replaced with standard growth medium. The cells were harvested $24 \mathrm{hr}$ later and glycogen content was measured. Due to the variability of absolute glycogen concentration in different cell lines, the data for each experiment were expressed as percentage of the glycogen concentration present in the cells on complete medium (i.e., complete medium $=100 \%$.

concentration of the cells was minimal at this point [7].

Glycogen concentration was measured on supernatants of cell lysates by the method described in the preceding paper [7]. Protein concentration was determined in the supernatants by the method of Lowry et al. [16].

For the data in Figure 1, glycogen concentrations were referred to protein determinations in whole cell samples rather than in supernatants of lysed cells. Insulin, bovine crystalline [21], was added to the medium to the concentration indicated for each experiment. Cytochalasin B [22] was dissolved in dimethyl sulfoxide $(1 \mathrm{mg} / \mathrm{ml})$ and stored at $-35^{\circ}$. The concentration used in all experiments was $1 \mu \mathrm{g} / \mathrm{ml}$ medium.

\section{Results}

\section{Influence of Glucose Concentralion in Medium on Metabolism of Glycogen (Fig. 1)}

Increasing the glucose in the medium from the usual concentration of $100 \mathrm{mg} / 100 \mathrm{ml}$ to 200 or $300 \mathrm{mg} / 100$ 
ml did not significantly enhance the amount of glycogen stored by the cells. Glycogen stores were maintained until glucose was essentially undetectable in the medium, then the polysaccharide began to decrease. As glucose disappeared, lactate accumulated in the medium; once glucose was exhausted and cell glycogen markedly depleted, lactate concentration decreased in the medium.

Factors Affecting Reaccumulation of Glycogen after Glucose Starvation: Effects of Serum and Insulin (Fig. 2)

After glycogen was depleted by glucose starvation, if glucose was again added to the medium, cells rapidly resynthesized the polysaccharide. The simple addition of glucose to glycogen-depleted cells caused a fourfold increase in the concentration of the polysaccharide in $24 \mathrm{hr}$. Addition of complete medium which contained the same amount of glucose induced an almost 10-fold increase of glycogen concentration. The elimination of either the amino acids or vitamins, or both, from the medium did not abolish the stimulating effect of otherwise complete medium on glycogen synthesis. The enhancement appeared to be due to the serum component. Serum dialyzed for $36 \mathrm{hr}$ against $0.15 \mathrm{M} \mathrm{NaCl}$ was similar to nondialyzcd serum.

Of many components of serum, insulin seemed most likely to be responsible. The effect of insulin $(4 \mathrm{mg} /$ $100 \mathrm{ml}$ ) in serum-free medium on glycogen resynthesis was similar to serum (Fig. 2). There was remarkable similarity in the proportionate response of the eight lines studied. Glycogen accumulations, expressed as mean percentage $( \pm \mathrm{SD})$ of glycogen in cells incubated with complete medium, were: no glucose, day $13,12 \pm$ 3.2; no glucose, day 14, $10.2 \pm 3.1$; glucose only, 44.8 \pm 4.8 ; glucose + insulin, $109 \pm 11$.

\section{Effect of Insulin Concentration on Glycogen Reaccu- mulation (Fig. 3)}

Only a doubling of glycogen content was achieved by increasing the insulin concentration from $4 \times 10^{-4}$ to $4 \mathrm{mg} / 100 \mathrm{ml}$. The glycogen level produced by 4 $\mathrm{mg} / 100 \mathrm{ml}$ insulin appeared to be maximal, since 40 $\mathrm{mg} / 100 \mathrm{ml}$ insulin did not further stimulate glycogen deposition.

Effect of Serum in Glycogen-depleting Medium on Subsequent Insulin Responses (Fig. 4)

Because there was no significant difference in glycogen synthesis by cells incubated with the lowest concentration of insulin $\left(4 \times 10^{-4} \mathrm{mg} / 100 \mathrm{ml}\right)$ plus glu- cose or with glucose alone, we considered the possibility that there was a residual effect on the control cells of the serum present during glucose starvation.

To check this possibility, two groups of cultures were grown on regular medium for 10 days. Then, for 3 days, one group was kept in serum-containing medium without glucose, the other group was maintained in serum-free medium without glucose. The effects of adding glucose, glucose plus serum, and glucose plus insulin $(4 \mathrm{mg} / 100 \mathrm{ml})$ were then tested. In two experiments, glucose alone had much less effect on glycogen

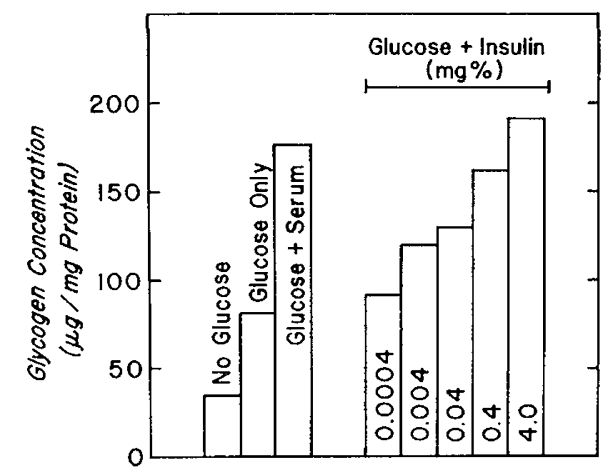

Fig. 3. The effect of insulin concentration on glycogen reaccumulation. Sixtcen cell cultures were depleted of glycogen (see Matcrials and Methods). Two cultures were then incubated for $24 \mathrm{hr}$ in cach of the following media and the cell glycogen contcnts detcrmined: without medium change (No Glucose), complete medium without scrum (Glucose Only), complete medium with sum (Glucose + Serum) complete medium without serum plus the various concentrations of insulin indicated (Glucose + Insulin).

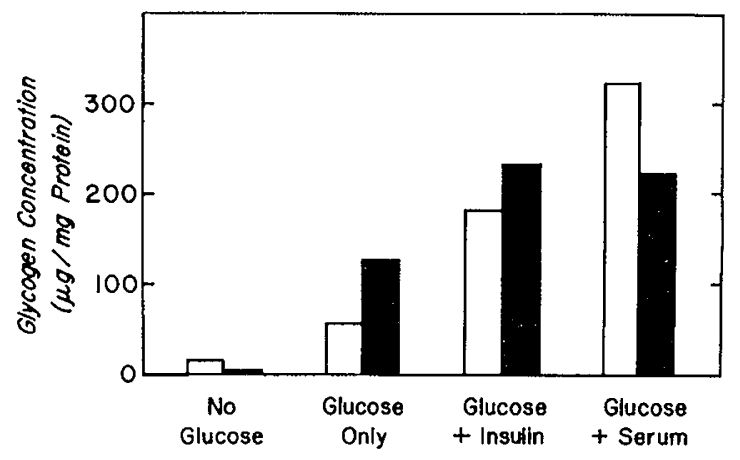

Fig. 1. Glycogen reaccumulation in cells depleted of glycogen by glucose starvation in the presence or absence of serum in the medium. 'Iwo sets of cight cultures wcre depleted of glycogen by incubation in medium without glucose, one with scrum $(10 \%$ $\mathrm{v} / \mathrm{v}$ ) (solid bars) and the other without serum in the medium (open bars). The cultures were then treated identically; two each were incubated for $24 \mathrm{hr}$ under the conditions indicated, and the glycogen contents of the cells determined. Sec legend of Figure 4 for details of incubation media. The insulin concentration was $4 \mathrm{mg} / 100 \mathrm{ml}$ in the glucose + insulin cultures. 
synthesis in cells previously deprived of both glucose and serum than in those deprived of glucose only. Insulin strongly stimulated glycogen synthesis in both groups. Serum restored glycogen when added after glucose deprivation only, and had even more pronounced effects on cells deprived of both glucose and serum. The effects were similar whether glycogen concentration was expressed per $10^{6}$ cells or per unit of protein, and therefore was not related to decreased protein content in these cells.

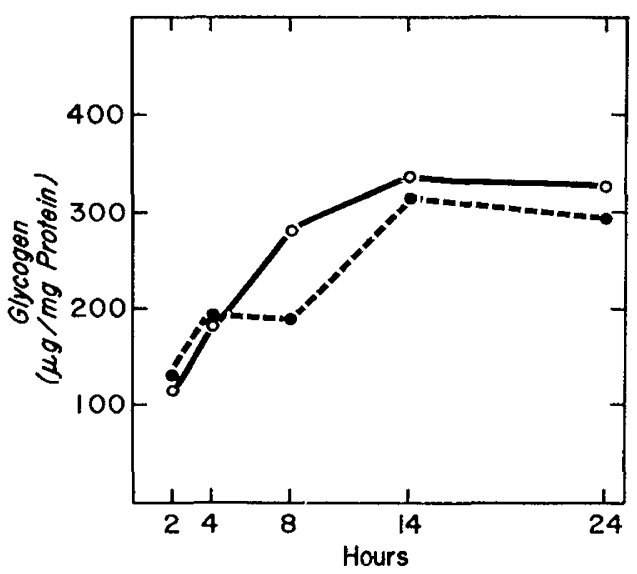

Fig. 5. Comparison of insulin and serum on the rate of glycogen storage in cells depleted of glycogen by glucose starvation. Twenty cultures of a cell line were depleted of glycogen (see Materials and Methods). Ten cultures were placed on medium containing serum $(\bigcirc-\bigcirc)$ and the other 10 on medium containing insulin $(4 \mathrm{mg} / 100 \mathrm{ml})$ but no serum $(\bullet---\bullet)$. Duplicate cultures were harvested at the times indicated, their cells pooled and glycogen concentrations determined.

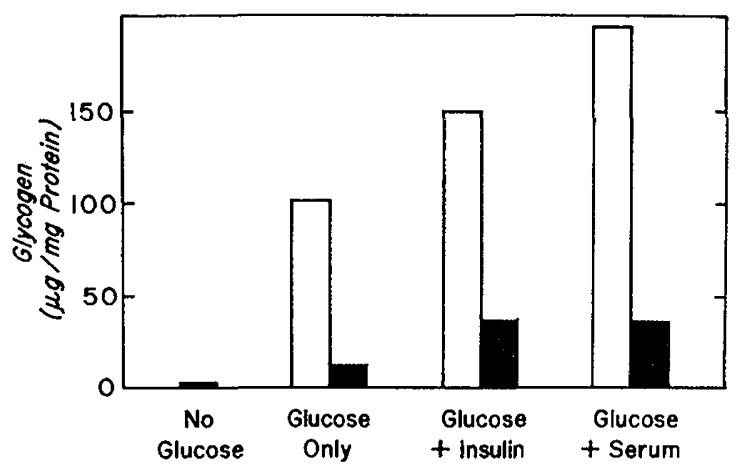

Fig. 6. The effect of cytochalasin B in glycogen reaccumulation. Cells wcre depleted of glycogen as described in Materials and Methods. Half of the cultures were treated with cytochalasin B $(1 \mu \mathrm{g} / \mathrm{ml})$ added as a final concentration to the various media tested and the other half received the vehicle (DMSO). Insulin, $4 \mathrm{mg} / 100 \mathrm{ml}$ was used in the glucose + insulin medium (+ cytochalasin, solid bars; no cytochalasin, open bars).
Effects of Insulin and Serum on Rate of Glycogen Reaccumulation (Fig. 5)

The rate of glycogen resynthesis after depletion was studied in serum-containing medium and in serum-free medium which contained insulin. In both conditions, glycogen deposition was rapid in the first $4 \mathrm{hr}$, then slowed, and was virtually arrested by $14 \mathrm{hr}$.

\section{Effect of Cytochalasin B on Glycogen Reaccumulation (Fig. 6)}

When cytochalasin $B$ was added to the culture medium $(1 \mu \mathrm{g} / \mathrm{ml})$, there was marked inhibition of glycogen deposition, whether the repletion medium contained glucose alone (88\% inhibition), glucose plus serum $(78 \%)$, or glucose plus insulin $(72 \%)$.

\section{Discussion}

These studies demonstrate that cells cultured from human skin biopsies store glycogen in substantial amount when sufficient glucose is available in the medium of culture. Glycogen is utilized by the cells when glucose is removed from the medium or its concentration has dropped to minimal levels by metabolism. This glycogen utilization permits the temporary survival of cells in the absence of a hexose source in the medium. Although these cells utilize the lactate that has accumulated in the medium, lactate appears to be an inadequate substitute for glucose; cell disintegration occurs in close temporal association with glycogen depletion, even when there is still considerable lactate in the medium. Thus, glycogen appears to be an important source of cell nutrition when glucose is absent from the medium.

The glycogen content of rapidly dividing human fibroblast cells was less than that of cultured cells in the slowed multiplication phase that occurs after cells have reached confluent density on their growing surface. Presumably, rapidly dividing cells utilize glucose in the medium as the substrate for macromolecular synthesis and the energy required for this synthesis, with less glucose available for glycogen storage. Slowly dividing cells were used in these studies of glycogen depletion and repletion; on repletion, cells attained the higher concentrations of glycogen found in slowly dividing cells.

The amount of continuing cell multiplication that occurs in human diploid fibroblast cells in culture varied from cell line to cell line, particularly after a cell line had been serially subcultured on multiple occa- 
sions. We suspect that the observed variation in glycogen content between cell lines is due to these differences in postconfluent cell multiplication.

Glucose, however, was not the only requirement for the resynthesis of glycogen when cells were starved of glucose and allowed to become depleted of glycogen. When only glucose was added, the amount of glycogen synthesized in the next 24 hr was less than half of the amount synthesized by cells on fresh complete medium that included glucose. The effect of glucose alone was even smaller when, to minimize the effect of residual serum factors, both glucose and serum were deleted from the medium for 3 days preceding the addition of the different experimental media. A serum factor, or factors, therefore, appears to be necessary for maximal glycogen deposition. Insulin might be one such factor; when the hormone and glucose were addled to glycogen-depleted cells, maximal glycogen accumulation occurred.

Insulin may not be the only serum factor, however, because cells depleted of glycogen by omitting both glucose and serum from the medium did not restore glycogen content as well with insulin and glucose as with serum and glucose. This, and the smaller effect of the addition of glucose alone under these conditions, indicate that cells depleted of glycogen by deletion of glucose only probably have residual serum factors adsorbed on their membranes.

Evidence for insulin receptors in cells similar to those used in these experiments has been reported [9]; such receptors, at least in cultured human lymphocytes, are released from the cell surface by incubation in serum-free medium [8].

Insulin probably enhances glycogen deposition in cultured fibroblasts by facilitation of glucose cntry into cells. Griffiths [10] observed that insulin increased the uptake of labeled glucose by cells of the diploid strain (WI-38) [10]. In his studies, the effect of insulin was greater on glucose-starved cells.

The concentration of insulin required to obtain the effect in the experiments of this report are excessive when the amount of insulin in serum is considered. However, in other cell studies of insulin effects, closes of insulin which were apparently pharmacologic were also required $[9-11,13,19]$.

In muscle, stimulation of glycogen deposition by insulin is due to both increased entry of glucose and a shift of glucose metabolism toward glycogen synthesis through activation of glycogen synthetase $[14,15]$. Insulin also stimulates glucose transport in human dip- loid cells, but, in contrast to muscle, it also enhances glucose utilization and lactate production via glycolysis [10]. There is no published information concerning the characteristics of glycogen synthetase of human fibroblasts. Results in our laboratory indicate that only the glucose 6-phosphate-dependent form of the enzyme is detectable, and wc are unable to detect the systems required for the interconversion of the glucose 6-phosphate-dependent and glucose 6-phosphate-independent forms of synthetase [1]. The presence of "serum factors" in the medium appears to be even more important in the culture of more differentiated tissues, such as skeletal muscle. De La Haba et al. [2, 3] described two serum factors required for the complete differentiation of muscle tissue in culture. One, identified as insulin, was needed for the fusion of myoblasts into myotubes. The other, unidentified, was required for differentiation to cross-striated, spontaneously contracting fibers and also promoted the appearance of glycogen synthetase.

Cytochalasin B markedly inhibited glycogen deposition in fibroblasts. Sanger and Holtzer [18] found that cytochalasin B, in a variety of cell cultures, strongly and rapidly depressed synthesis of mucopolysaccharides and glycoproteins. They suggested that alterations of the cell surface affected cell mobility, cell adhesion, and cell sorting-out. An alteration of the cell membrane may also alter the stereospecific sites presumed to be involved in glucose transport [20]. The moderate protective effect of insulin on the action of cytochalasin $B$ suggests competition for these sites. Because the specific effects of cytochalasin $B$ are not known, inhibition of glycogen synthesis by different mechanisms cannot be excluded. We found no inhibition of glycogen synthetase activity in cells incubated with the drug. Furthermore, there was no inhibition of synthetase activity when cytochalasin $B$ was added directly to the assay system [4].

\section{Surnmary}

The dynamics of glycogen can be studied in cultures of human skin fibroblasts. Factors that influence glycogen concentration include: stage of cell multiplication, glucose concentration in the medium, and serum factor or factors. Glycogen-depleted cells resynthesize glycogen to maximal levels in 14 hr; either serum or insulin is needed for this resynthesis. However, the concentration of insulin required under the conditions of these experiments is nonphysiologic. Cytochalasin B, as 
might be predicted from its role in blocking glucose transport, inhibits glycogen resynthesis.

\section{References and Noles}

1. Brow', B. I., AND Brown, D.: The experimental production of glycogen storage in cultured human fibroblasts. Biochem. Biophys. Res. Commun., f6: 1292 (1972).

2. De la Haba, G., Cooper, G. W., and Elting, V.: Holmonal requirements for myogenesis of striated muscle in vitro: insulin and somatotropin. Proc. Nat. Acad. Sci. U. S. A., 56: $1719(1966)$.

3. De La Haba, G., Cooper, G. W., and Ei.tine, V.: Myogenesis of striated muscle in vitro: Hormone and serum requirements for the derelopment of glycogen synthelase in myotubes. J. Cell Physiol., 72: 21 (1968).

4. DiMauro, S.: Unpublished results.

5. Dimauro, S., Mellman, W. J., Oski, F. A., and Bakfr, L.: Glycogen and hexose metabolism in fibroblast cultures from galactosemic and glycogenosis type II patients. Pediat. Res., 3: 368 (1969).

6. Dimauro, S., Mellanan, W. J., ani Rowi.and, L. P.: Human fibroblasts in culture: Further studies of glycogen metabolism. Pediat. Res., 6: 359 (1972).

7. Dimauro, S., Rowland, L. P., and Mellman, W. J.: Glycogen metabolism of human diploid fibroblast cells in culture. I. Studies of cells from patients with glycogenoses type II, III, and $V$. Pediat. Res., 9: 739 (1973).

8. Gavin, J. R., Buell, D. N., AND Roth, J.: Water-soluble insulin receptors from human lymphocytes. Science, 178: I68 (1972).

9. Gavin, J. R., Roth, J., Jek, P., and Freychet, P.: Insulin receptors in human circulating cells and fibroblasts. Proc. Nat. Acad. Sci. U. S. A., 69: 747 (I972).

10. Griffiths, J. B.: The effect of insulin on the growth and metabolism of the human diploid cell, WI-38. J. Cell Sci., 7: 575 (1970).

11. Goldstein, S., And Littlefield, J. W.: Effect of insulin on the conversion of glucose-C-14 to $\mathrm{C}-14-\mathrm{CO}_{2}$ by normal and diabetic fibroblasts in culture. Diabetes, $18: 545$ (1969).

12. Hayflick, L., and Moorhfad, P. S.: The serial cultivation of human diploid cell strains. Exp. Cell Res., 25: 585 (1961).

13. Hershoo, A., Mamont, P., Shields, R., and Tomkins, G. M.: "Pleiotypic response." Nature New Biol., 232: 206 (197I).
14. Levine, R., ANd HaFt, D. E.: Carbohydrate homeostasis. I. New Engl. J. Med., 283: 175 (1970).

15. I.evinf, R., AND HAFt, D. E.: Carbohydrate homcostasis. II. New Engl. J. Med., 283: 237 (1970).

16. Lowri, O. H., Rosebrovgr, N. J., FARr, A. L., And R.Andall, R. J.: Protein measurement with the Folin phenol reagent. J. Biol. Chem., 193: 265 (1951).

17. Pallavigini, J. C., Wifsitann, U., Uhlendorf, W. B., and DiSAnt'Agnffs., P. A.: Glycogen content of tissue culture fibroblasts from paticuts with cystic fibrosis and other heritable disorders. J. Pediat., 77: 280 (1970).

18. SANGer, J. W., AND HolTzER, H.: Cytochalasin B: Effects on ccll morphology, cell adhesion, and mucopolysaccharide synthesis. Proc. Nat. Acad. Sci. U. S. A., 69: 253 (1972).

19. Schwart\%, A. G., ANd Amos, H.: Insulin dependence of cells in primary culture: Influence on ribosome integrity. Nature, 219: $1366(1968)$.

20. Zignonn, S. H., ann Hirscri, J. G.: Cytochalasin B: Inhibition of $\mathrm{D}$-2-deoxyglucose transport into leukocytes and fibroblasts. Science, 176: 1432 (1972).

21. Sigma Chemical Company, St. Louis, Mo.

22. Imperial Chemicals, Ltd., Lonclon, U.K.

23. For the studies involving human subjects reported in this paper, written informed consent has been obtained in accordance with the provisions of the Declaration of Helsinki.

24. The authors acknowledge with gratitude the following help with the studies reported in the present and the preceding paper: to E. Soffian and B. Needleman, who prepared the cell cultures; to G. Kohn, M.D., and G. Jackson, who obtained the biopsy material and established the cell lines; to T. Tedesco, Ph.D., who gave scientific advice; to J. Sanger, Ph.D., who provided the cytochalasin B; and to L. Baker, M.D., who allowed us to study his patients and performed lactate determinations.

25. This work was presented in part at the 82nd Mceting of the American Pediatric Society, Washington, D.C., May 1972 [6].

26. This research was supported by Grants nos. HD-00588, HD15545, and NS-08075, United Statcs Public Health Service, and a grant from the Muscular Dystrophy Associations of Americal.

27. Requests for reprints should be addressed to: SaLvatore DrMauro, M.D., Department of Neurology, University of Pennsylvania School of Medicine, 429 Johnson Pavilion, 36th St. and Hamilton Walk, Philadelphia, Pennsylvania 19174 (USA).

28. Accepted for publication $\Lambda$ pril 10, 1973 . 